\title{
Paradise Lies at Her Feet: The Status of Women in Islam
}

\author{
Sadaf Zaman
}

\section{INTRODUCTION}

The prevailing perception of women in Islam is considered as Oppressed, inferior, and unequal, but in contrary Islam has empowered women with the most progressive rights since the 7 th century. In Islam, women are not inferior or unequal to men. Rather the Almighty Allah has devoted an entire chapter (Surah Al Nissa) of the Quran, the holy book of Islam, to women. In addition, Allah directly addresses women repeatedly throughout the Quran. Islam proclaims that all human beings, men and women, are born in a pure state. The goal of every Muslim is to preserve this purity by shunning evil tendencies and beautifying their inner being with virtuous traits.

Islam is a religion of balance; balance between the materialistic and the spiritual; balance between work and worship; balance between self-preservation and selflessness. Islam as a religion seeks first to maintain that balance in man and then guides man to maintain that balance in society and the eco-system which plays host to the human society.One of the first things Islam did was to demolish all the artificial barriers of social injustices such as, claims of superiority of one group over the other and discriminations on the basis of sex, lineage, tribe, race, etc. in the famous verse: "O Mankind we created you from a single (pair) of a male and female, and made you in to nations and tribes, that ye may know each other (not that ye may despise each other). Verily the most honored of you in the sight of God is (he who is) the most righteous of you. And God has full knowledge and is well acquainted (with all things)."

Islam confirms that both men and women are equal in the sight of Allah. At another place in the Quran, Allah clearly states that all humans are equal: "To whoever, male or female, does good deeds and has faith, We shall give a good life and reward them according to the best of their actions." (16:97)

It is unfortunate to notice that one of the most beautiful creations of the Almighty Allah is suppressed in the name of Islam in society which is in contrary highly condemned by Islam and the beloved messenger of Allah Prophet Mohammed (PBUH). In this paper, I would like to discuss the glorious position gifted to women by Islam.

First of all I will talk about freedom in Islam which is considered to be a natural right of the human being. But according to many people there are many boundaries for girls in terms of the freedom of education,marriage,divorce,job, etc. In reality, girls are as free to receive education as boys are. "It is obligatory for every man and woman to receive education." Education and training in etiquette is the best gift of parents to children. A girl cannot be married off to anybody without her consent. As man has liberty to divorce; a woman is also allowed to take "khula" (divorce) if she dislikes her husband who is cruel, unjust or impotent. A widow or a divorcee is allowed to re-marry if she wishes. It is a myth that is ruling the society that women should remain at home to look after the family and train children. Still Islam says if no male guardian lives with her or if he is ill or his income is insufficient, she may go out to earn but in hijab. During the time of Prophet Muhammad (peace be upon him), there were women traders and there were instances when women participated in wars to supply water or to nurse the wounded. At present thousands of Muslim women in hijab work in hospitals, banks, schools, colleges and many other congenial working places.

Next I would like to explain equality in Islam. Allah (S.W.T.) says in surat Al-Hujurat, (verse 13), what be translated as, "O Mankind! We have created you from a male and female, and made you into nations and tribes, that you may know one another. Verily, the most honorable of you in the sight of Allah is he who has most taqwa among of you. Verily, Allah is All-Knowing, All-Aware."

With this verse, Islam declares equality among people, that is because Islam respect a human for being a human not for any other reason. There is no gender disparity in Islam. "And whoever does righteous good deeds male or female - and is a true believer in the Oneness of Allah, such will enter Paradise and not the least injustice, even to the size of a Naqira (speck on the back of a date-stone), will be done to them." (Qur'an, $4: 124)$. Women are equal to men in all civil and criminal acts of judiciary.

Furthermore the security of woman in Islam is very important. She is not inferior to a male. "The person to whom a daughter is born and he does not ... mete out preferential treatment to boys, Allah will reward him with heaven." (Hadith i.e. saying of the Prophet). Parents are motivated to nurture girls. The responsibility to provide bread and butter to girls and women lies with the male guardian. "You should feed her when you eat, and clothe her when you yourself put on clothes. And in case of temporary boycott due to strained relations, it should be limited to the four walls of your house." (Hadith). The Qur'an strongly warned not to kill and express 
anger at the arrival of the female child, describing graphically the attitude, it says, "When the news is brought to one of them, of (the birth of) a female (child), his face darkens, and he is filled with inward grief!" (Q. 16:58). This is a very good instance to prove that how a female has been blessed by the Almighty Allah as He has ordered the parents to welcome them with all happiness and open arms, and raise them with immense tender and love which they happen to give to other gender.

With regard to financial security, itis assured for women as they receive money in the form of maritalgift (mehr) without limit and she can keep present and future properties and income for their own security. Even after marriage she has a lawful share in property. "For men is a share of what the parents and close relatives leave, and for women is a share of what the parents and close relatives leave, be it little or much - a legal share." (Qur'an, 4:7). Even the Shari'ah (Islamic Law) recognizes the full property rights of women before and after marriage. They may buy, sell or lease any or all of their properties at will. For this reason, Muslim women may keep (and in fact they have traditionally kept) their maiden names after marriage, an indication of their independent property rights as legal entities. She also has the right to work and spend the money she earns as she wishes. She has no obligation to share her money with her husband or any other family members, although she may choose to do so out of good will. For instance, Khadija, the wife of the Prophet Muhammad (pbuh), was one of the most successful businesswomen of Mecca, and she freely spent from her wealth to support her husband and the cause of Islam.

The last but not the least, I would like to discuss a very sensitive issue, marriage which happens to be the most misinterpreted topic. In Islam, marriage is based on mutual peace, love, and compassion. Allah (SWT) says about Himself, "And of His signs is that He created for you from yourselves mates that you may find tranquility in them; and He placed between you affection and mercy..." (Quran 30:21). A woman has the right to accept or reject marriage proposals and her approval is required to complete the marriage contract. She cannot be forced to marry someone against her will and if this occurs for cultural reasons, it is in direct opposition of Islam. By the same principle, women also have the right to seek divorce if they are dissatisfied with their marriage. A very unique aspect of marriage in Islam is 'polygamy' which allows a man to keep four wives at a time; but unfortunately, it has been very dangerously misunderstood by throughout the world.The Muslim scripture, the Quran, is the only known world scripture to explicitly limit polygamy and place strict restrictions upon its practice:

“... marry women of your choice, two or three or four; but if you fear that you shall not be able to deal justly with them, then only one." (Quran 4:3).

If you read the verse very carefully,you might assure yourself that the Quran limited the maximum number of wives to four.People have molded it according to their desire of marrying more than once;woefully, they omit the last part of the verse which according to them may not have much importance but surely Allah has made in this verse very clear that the Muslim is not permitted to differentiate between his wives in regards to sustenance and expenditures, time, and other obligations of husbands. Islam does not allow a man to marry another woman if he will not be fair in his treatment. Prophet Muhammad forbade discrimination between the wives or between their children.

We should not forget to mention the fact that in this modern and developing era Muslim women are not lacking behind. Many women have taken leaps and strides in the developed world where we see Muslim women who have obtained an education, deliberate their own future and make choices which can enhance and improve their quality of life. Coming from a practicing Muslim background I have witnessed no discrimination between me and my brother. Both of us are raised equally and given parallel opportunities to excel in our endeavor be it like education, marriage, job etc. Even being a practicing Muslim I feel myself independent and confident and at the same time I feel proud to witness that many Muslim women have grounded their feet in many different fields in the recent years, be it like Dalia Mogahed, one of the closest advisor of Barak Obama, or Nadia Hussain, who bagged the competition at"The Great British Bake Off", or Ibtihaj Muhammad, ranked as one of the best female fencer in the world or Tawakkul Karman, a well known journalist, politician and human rights activist who won Noble Peace Prize. The list is unending as it goes on and I pray that the number of Muslim women achiever continues to increase in the coming years.

I would like to conclude by saying that Islam has an extensive tradition of protecting of women based on the guidelines set forth by the Almighty Allah and His Prophet. Women are empowered with many rights and protections under Islamic law and are honored with a dignified stature in society.

SadafZaman

Research Scholar

Kolhan University

Chaibasa, Jharkhand. 